\title{
PERSPECTIVES OF DEVELOPMENT OF GREEN JOBS IN BULGARIA ${ }^{1}$
}

\author{
Zornitsa Stoyanova ${ }^{2}$, Hristina Harizanova ${ }^{3}$
}

\begin{abstract}
Summary
The transformation to green sectors of the economy in Bulgaria leads after it the need of new type of professions, which would be capable to cope with the new conditions and requirements which different businesses are facing.

The knowledge of creation of green jobs in Bulgaria is insufficient, which makes this paper state of art. Green jobs in Bulgaria are connected with transfer of business activities to green ones. The paper analyzes and evaluates the current conditions of creation of green jobs in Bulgaria. It is proposed analysis of the requirements in Bulgaria about the eligible criteria to apply for funding under the measurement of green jobs; based on research SWOT analysis of creation of green jobs. The results are systematized in findings, conclusions and policy recommendations, as changing conditions of applying to measurement, payment connected to employees, and etc. As well is proposed cooperation between other existing measurements for reaching sustainable employment in Bulgaria.
\end{abstract}

Key words: green jobs, sustainability, SWOT, policy recommendation.

JEL: Q01, Q58

\section{Introduction}

Green growth is the only form of sustainable development in the future for Bulgaria, Europe and the world. Green jobs are created in the EU, mainly as a result of environmental solutions related to the fight against climate change. Industry and environment need to work together because in long-term interests are to achieve sustainability. Developing a green economy will generate a new workforce and transfers between sectors and labor markets on national and international level. One of the methods is by creating green jobs to support employment focused on energy efficiency initiatives to prevent climate change,

1 Paper is a part of research within the project Green jobs - tool of ecologisation of Bulgarian Economy (Miteva, Doichinova, Stoyanova, Kanchev, Harizanova, Peicheva and etc, 2014).

2 Zornitsa Stoyanova, Ph.D., Associated Professor, University of National and world Economy, Studentski grad 1700, office 1065, Sofia, Bulgaria, Phone: +359 28195 460, E-mail: zori_stojanowa@yahoo.de

3 Hristina Harizanova, Ph.D., Chief assistant professor, University of National and world Economy, Studentski grad 1700, office 1065, Sofia, Bulgaria, Phone: +359 28195 460, E-mail: h.harizanova@gmail.com

EP 2015 (62) 2 (369-384) 
environmental technologies and others. Green growth is a form of sustainable development and green jobs support this process (EC, 2013). The world-wide goals of sustainable growth, jobs, poverty reduction and equitable development cannot be achieved unless directly tackled at the rural level and green jobs are the connection (Luca, 2011). In official papers of European commission for "Rural development strategies" (EC, 2014) green jobs are directed as a way for reaching sustainability.

Although in Bulgaria the green job is not still very well researched, there are evidences of international experiences. Many authors (Sharma, 2011; Renner, 2008) describe green jobs, as a decent and not decent. As a definition is used "....work that helps bring about and maintain a transition to environmentally sustainable forms of production and consumption" (Sharma, 2011). According to the author there is still a big gap between green professions and decent work.

Other authors (Llewellyn, Hendrix, 2008) are stressing the need of green job, as a tool for increasing employment. Furthermore the concept of green jobs is described as a tool for synergies in simultaneously between employment, energy and environment issues (Jacobs, 1994). Green jobs, employment that contributes to protecting the environment and reducing humanity's carbon footprint, will be a key economic driver of the 21 st century. Green jobs will play a role within the various industries, energy production, construction, transportation, energy-intensive industries, recycling and re-manufacturing, and agriculture and forestry (Renner et al., 2008). Some author's opinion is that in developed economies, environment related jobs tend to be concentrated in activities directly linked to decarbonizing energy supply and improving energy efficiency, pollution control and eco-friendly services (Jarvis et al., 2011). Farrell (2011) summarized most popular green professions according a research. By his point of view most suitable for green transformation of the economy are professions as: ecotourism, sustainability coordinators, city planning professional, sustainable education, hydrologist, waste disposal specialist, park ranger, camp counsellor, animal conservationist, and etc.

On international level on problems of implementing green activities incl. green jobs is working International labour office (ILO), Department of statistics. Experts (Stoevska, Hunter, 2012) are exploring best practice and they state that green economy is not replacement for sustainable development, but it means to achieve it. They gave ILO's definition of green job according Green Jobs Program. It includes that green jobs will support environment and this will happen by:

- $\quad$ Reduce consumption of energy and raw materials;

- $\quad$ Limit greenhouse emissions;

- Minimize waste pollution;

- $\quad$ Protect and restore ecosystems.

The authors of the paper use definition of green jobs given by UNEP (UNEP/ ILO/IOE/ ITUC, 2009) and it defines green jobs as “... work in agricultural, manufacturing, research 
and development (R\&D), administrative, and service activities that contribute substantially to preserving or restoring environmental quality. Specifically, but not exclusively, this includes jobs that help to protect ecosystems and biodiversity; reduce energy, materials, and water consumption through high efficiency strategies; de-carbonize the economy; and minimize or altogether avoid generation of all forms of waste and pollution".

\section{Methodology}

There are different specifications of the green professions in EU countries, including Bulgaria and each country is free to define and observe the creating of green jobs. Complete and unified model for the creation of green jobs could not be applied. That is why each country is trying to propose and develop own approach for reaching the results of creation of green jobs. In the paper are described the specific conditions and perspectives in front of that type of employment.

Findings and conclusions in the paper are based on the results of university researched project Green jobs - tool of ecologization of Bulgarian Economy (Miteva et al., 2014).

The main aim of the paper is to analyze and evaluate the current conditions of green jobs in Bulgaria and on this basis to systematize findings, conclusions and policy recommendations.

The publication is divided into several parts. The main tasks are to:

1) Analyze the legal framework for the creation of green jobs;

2) Describe and evaluate the perspectives and barriers in front "green jobs" in Bulgaria;

3) Propose policy recommendations and general conclusions.

In the first part - Legal framework for the creation of green jobs is given general overview of the current condition of policy in Bulgaria connected to green jobs. This part is mainly literature based and is used systematic approach for gathering and analyzing the legal framework. Here is made comparison among three sides: employer, employee and government. The legal framework in the sector presents the requirements of the measure for employer, such as the requirements for employee. Main place is taken by sectors of support and alternative employment measures in Bulgaria.

In the second part of the paper - Perspectives and barriers in front green jobs in Bulgaria are developed on systematical approach. The content includes:

1. State of art of potential jobs in the EU, which can be transformed into green or are already green. This part is organized as analysis and shows what is Bulgarian background compared by several statistical criteria: number of potential employment of green jobs on EU level, percentage of total employment related with green jobs; development of the payment of the measure "Green jobs" and eligible payment by it.

2. Analysis of the requirements in Bulgaria about the eligible criteria which employers need to obtain to be able to apply for funding under the measurement of green jobs. The two main conditions ISO 14001 and EMAS are tracked on EU level and Bulgaria 
is compared with the data. The used approach in this part is comparative. The used data is gathered by the official statistic of the EU countries and Bulgarian National statistic.

3. SWOT analysis of creation of green jobs, which is according research under the project. The survey was conducted in December 2014. Information is summarized on the basis of meetings with experts from municipal and regional structures involved in the implementation of green jobs in the country.

Third part of the paper presents policy recommendations and general conclusions. As a result of meetings with experts, steak holders, business structures and employers are revealed gaps in the existing policies in the sector. On this base are summarized general conclusions.

\section{Legal framework for the creation of green jobs}

In 2010 a new measure for the creation of green jobs was introduce by amendment of the Law for Promotion of Employment. It aims to encourage employers who create jobs in economic activities which support environmental protection. This measure follows one of the leading priorities in the Europe 2020 - the strategy for development of environment friendly and competitive economy, which use resources more efficient (Ministry of Labour and Social Policy, 2014).

The law define as "green" jobs those which are launched in economic activities related to production of goods and provision of services supporting the environment, according to a list of economic activities approved by the Minister of Environment and Water and the Minister of Labour and Social Policy in 2010. It is updated every year.

The employer should recruit more than one sequential unemployed person directed by employment offices. Employers may pay a higher remuneration of the funds granted by the State, and to detain for a longer time hired workers. Promoting measure provides financial sources for each opened green job, on which was hired an unemployed person directed by the division of the Employment Agency for the time during which the person has been employed, but for no more than 12 months. It is necessary the employer to reveal green job and to keep hired persons at least 6 or 8 months. The social security contributions are not paid out under the measure for green jobs, so the employer needs to pay them out from his own budget (Employment Agency, 2010).

The application procedure for green jobs is related to that employer who wants to use this preference. Application form about vacancies and the necessary application documents must be submitted to the Employment office. The employer must describe written to the employment office the nature of the work, educational and training requirements for the applicant and the procedure for selecting candidates. Requests are registered and entered into an automated information system. After approval by the Collaboration Council, the employer signs a contract with an approved model for hiring people in employment offices for allocation from the State budget.

All employers who are certified in one of three certification marks - environmental standards 
ISO: 14001, management of the environment / EMAS / and European Eco-label scheme are eligible for applying. Some industries, aimed to improving the environment can apply without the need to have these certificates. These are the sectors mainly related to waste water treatment, waste management, waste sorting, recycling, reuse of waste, production waste eco materials and products made from waste wood, the production of energy efficient equipment, environmental transport, etc.

The candidate for a green job, have to be unemployed person, who is registered not less than 6 months in Local employment office. Registration requires many documents such as identity document; applying - declaration established in a form approved by the Executive Director of Employment office; proof of address registration at the current address; documents acquired education and / or qualification; documents that certify retirement. In this connection for each registered person shall be issued a registration card.

Economic activities linked to the production of goods and provision of services supporting environment are divided into seven sectors. They are presented on scheme 1. 
Scheme 1. Economic activities by sectors

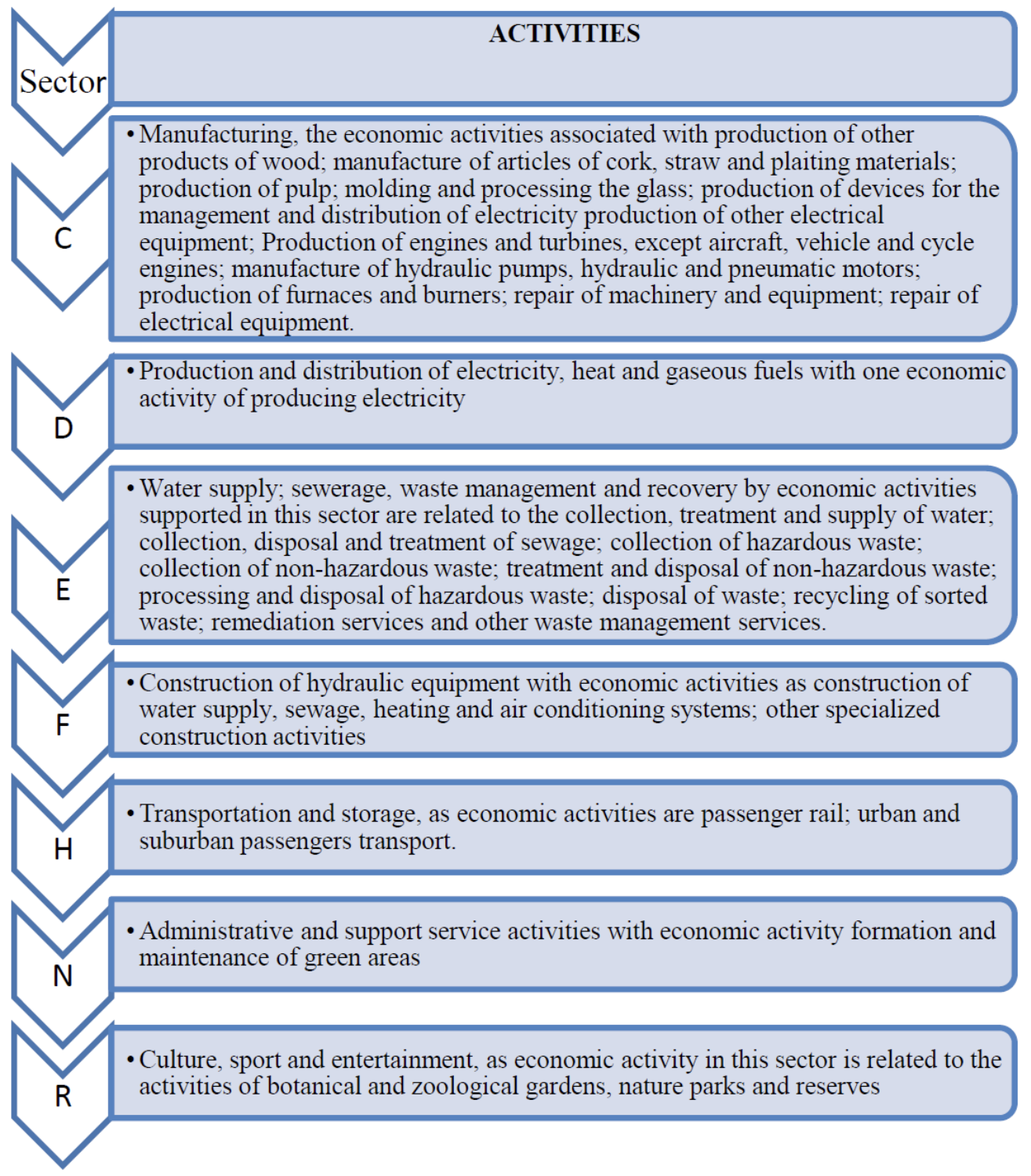

Source: Employment agency, 2010.

Registered in the Employment offices unemployed persons may be directed to green jobs if their registration has been maintained not less than 6 months. They can occupy the following positions according to the National Classification of occupations:

$\checkmark$ Qualified workers and related crafts;

$\checkmark$ Machine operators and assemblers; 
$\checkmark$ Professions which don’t require special qualification: workers for waste collection or workers sorting waste etc.

Funds for measure "Green jobs" are provided to employers by the recruitment of an unemployed person directed by the Employment office. Employers must provide a set of documents, such as: a written application form; written request to direct unemployed to work in announced vacancies; written agreement with the local employment office; a written declaration that the person doesn't have public obligations, obligations for noncontracted programs, measures and training as well as projects under the Operational Programme "Human Resources Development"; letter from the National Statistical Institute to determine the code of the main economic activity of the employer; a copy of the document certifying the registration under the scheme EMAS, implemented system of environmental management according to standards BDS EN ISO 14001, EN ISO 14001 or ISO 14001; awarded right to use the eco-label of the Community.

There are as well some specific requirements and documents if green jobs is created in a sector such as economic activity in Sector D "Production and distribution of electricity, heat and gaseous fuels". The employers need to give a copy of the "Guarantee of origin", issued by the Agency for Sustainable Energy Development.

In Bulgaria different employment measurement exist which are competing with green job measure. Main popular incentives for employers are - recruitment of persons under 29 years old; measure for long-term unemployed, a measure of recruitment for a part-time internship and etc. The applying procedure for some of these measures is more simple then this one of green jobs. In the same time the benefits for both sides (employer\& employee) are equal or higher to the other not green employment measurements. This may leads to redirect unused funds from measure "green jobs" to other measures that are more attractive to employers.

\section{Perspectives and barriers in front green jobs in Bulgaria}

The transforming of professions in the EU to green ones is based on green technology and economic activities influenced by increased demand of unique type of work (OECD, 2012). By using this definition, are identified three categories of professions that are subject to a green economy:

- New green professions;

- Existing professions which are updated with new skills related to green economy;

- Employers who convert to green activities.

Green jobs largely differ from traditional professions. In most European countries, the new green jobs are directed to sectors of renewable energy, construction sector, energy efficiency, waste and transport. Each country makes own rules what exactly is a "green profession" and what requirements have to obtain one working place to be called "green". 
As already was mentioned in previous part of the paper the environment standards are the first step a firm to transform its activity to environmental friendly ones. The potential for job creation is linked to the production of renewable energy, energy efficiency, waste management and water, air quality, restoration and conservation of biological diversity and the development of green infrastructure. All this new type of jobs could bring significant and sustainable changes in the business cycle.

Green jobs are created in the EU, mainly as a result of environmental solutions related to the fight against climate change. However, when EU focuses the attention to green jobs the purpose was aimed mainly to support organizations to transform to green activities. Table 1 presents the potential positions which can be called as green jobs in EU.

Table 1. Potential jobs in the EU, which can be transformed into green or are already green

\begin{tabular}{|l|c|l|c|}
\hline \multicolumn{1}{|c|}{ Country } & Number & \multicolumn{1}{c|}{ Country } & Number \\
\hline Germany & 361,360 & Romania & 16,800 \\
\hline France & 174,736 & Greece & 12,920 \\
\hline Italy & 108,150 & Hungary & 11,550 \\
\hline Spain & 98,300 & Latvia & 9,300 \\
\hline Sweden & 54,780 & Slovakia & 7,030 \\
\hline Finland & 48,620 & Lithuania & 5,850 \\
\hline Austria & 41,600 & Bulgaria & $\mathbf{5 , 4 7 0}$ \\
\hline Denmark & 36,400 & Ireland & 3,500 \\
\hline UK & 31,700 & Slovenia & 3,375 \\
\hline Poland & 28,450 & Estonia & 3,100 \\
\hline Belgium & 22,670 & Cyprus & 1,095 \\
\hline Czech Republic & 20,200 & Luxembourg & 500 \\
\hline Holland & 19,180 & Malta & 150 \\
\hline Portugal & 17,450 & Total & $1,144,236$ \\
\hline
\end{tabular}

Source: Sustainlabour, 2013.

Table 1 shows that Bulgaria is on bottom not only on nominal base, but on ratio as well, because the possible green jobs compared with total employment are $0.17 \%$, where in Germany this percent is over 7\% and they are planning to increase more. At the same time this is possible projection of employment.

Table 2 presents total number of green jobs and monthly salary for created green jobs in Bulgaria. The real situation of registered green jobs in Bulgaria is 515 (2013) of which only 400 are new working jobs (Table 2). For 2014 this number is decreasing and reaching bottom to 276 of which 100 new working places. This negative trend can be explained with very high requirements on one hand for the employers and on other hand very low payment for the employees. Under this measurement according to Employment agency the payment is the minimum salary to the workers. As well in the policy as a weak point can be mentioned that this payment is lower than the minimum wages for the some of the sectors. According on statistic data given by Capital Market SA more than a half of firms with ISO 14001 are in construction sector. 
Table 2. Green jobs under measurement of green employment

\begin{tabular}{|c|c|c|}
\hline Year & $\begin{array}{c}\text { Total number of green } \\
\text { jobs }\end{array}$ & $\begin{array}{c}\text { Monthly salary, BGN } \\
\text { (1 Euro= 1.95583 BGN) }\end{array}$ \\
\hline 2011 & 795 & 270 \\
\hline 2012 & n./a. & 290 \\
\hline 2013 & 515 & 310 \\
\hline 2014 & 276 & 340 \\
\hline
\end{tabular}

Source: Authors calculation based on data of Employment agency statistic.

The summarized field of activities of those firms is dedicated to high construction and associated infrastructure; high, low and hydro construction (buildings and structures, objects of technical infrastructure-water, sewage, hydraulic, energy, transport, etc.); construction of civil, industrial and infrastructure projects, construction, repair and reconstruction of the transmission, distribution, industrial and building pipelines for steam, hot water, gas, oil and other combustible fire resistant fluids; design, construction and repair of roads, buildings, water and sewage systems, earthworks and other construction works etc. These activities are mentioned because the minimum wage of the salary which is by low in Bulgaria starts from 360 BGN for unqualified jobs and reaching 825 BGN for management positions. Conclusion can be made that if any firm wants to use government support for creating green jobs have tree possibilities: 1- to hire only unqualified jobs and opening positions which do not require special education or qualification; 2 - to hire management positions to which they can use that payment as a supporting additional payment; 3 - to redirect employment to other programs, which may pay social security, which in program for green job is not included.

\section{Implementation of ISO 14001 in Bulgaria as a requirement of green jobs}

The implementation of standard ISO 14001 by stakeholders from business, industry, public authorities and non-governmental organizations shows concerns of the organization to reduce global pollution by controlling the impact of the environment with their activities, products or services and is needed requirement to create green jobs. ISO 14001 was adopted as a national standard by more than half of the national members of ISO community and its promotion by governments all around the world.

In Bulgaria according a survey made on EU level in registers can be found 1373 firms which implemented ISO 14001(2013). The figure 1 presents the development of ISO since 2001 up to 2013 , and is made power trend for 2014, 2015, which shows that at the end of the year the firms could be around 1500 and above. According to that information we can conclude that is possible around 1500 firms in the country to be able to launch green jobs.

Bulgaria is on $17^{\text {th }}$ place in Europa of number of firms which has ISO 14001. The statistic is very positive according to the small size of the country. The top three countries for the total number of certificates worldwide are China, Japan and Italy. The leaders in EU are Italy with 24662 firms, UK - 16879 and Spain with 16051. 
Nearly 50\% (49\%) of the firms implemented ISO 14001 up to 2014 in Bulgaria are in "Construction (building) sector", followed by "Public administration sector and defence; compulsory social security" (7\%), "Real estate, renting and business activities (5\%)" (Harizanova, 2015; Peicheva et al., 2014).

Figure 1. Development of ISO in Bulgaria 2001-2015

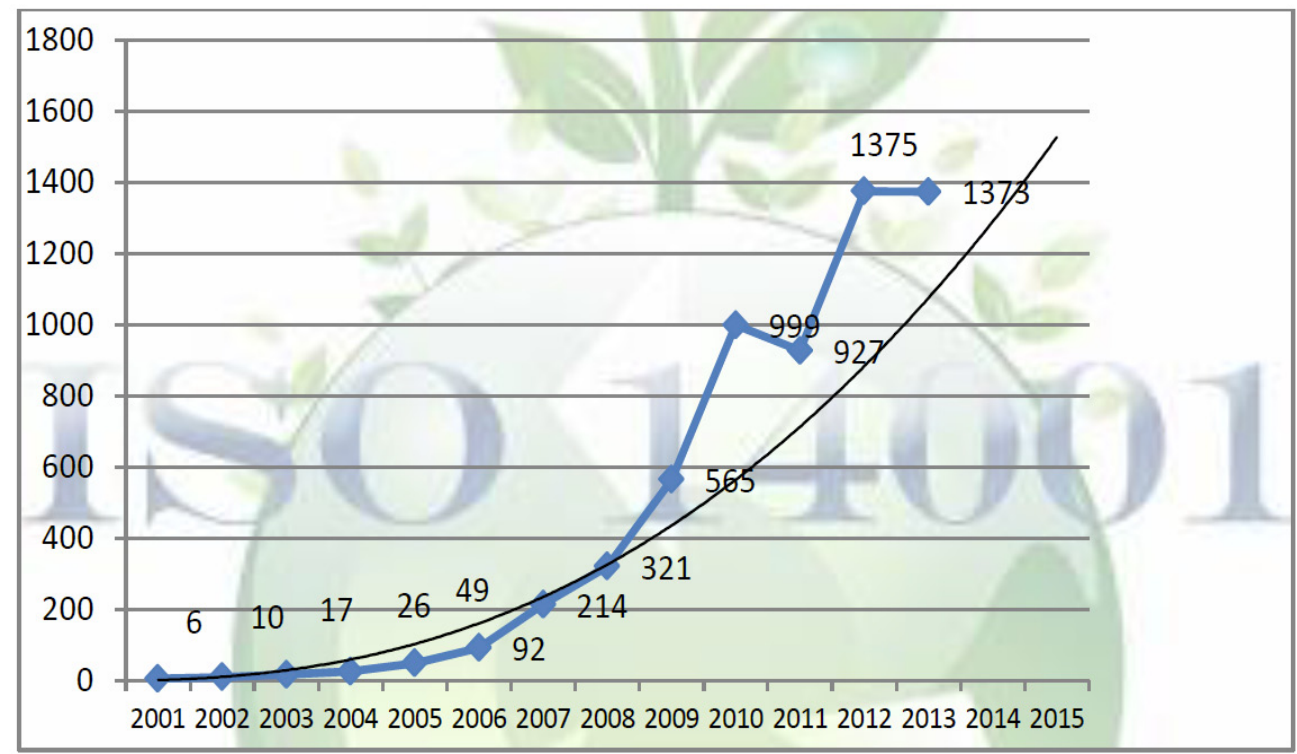

Source: Authors calculations based on data of IOS (2013).

With equal percentages of distribution (5\%) are the sectors:

- real estate,

- renting and business services,

- manufacturing of electrical and optical equipment,

- trade,

- repair of motor vehicles,

- motorcycles and personal belongings and household goods,

- metallurgy and manufacture of fabricated metal products,

- machinery and equipment.

In agriculture, hunting and forestry, which is traditional for our country has only 4 companies that have managed to obtain 14001 certificates. Their main activities are: - Construction and maintenance of park and decorative areas, sports fields and playgrounds, playgrounds, irrigation systems, landscaping and more. According to the collected data is seen that there are no in firms operating in agriculture which have ISO 14001 certificate. 


\section{EMAS (Eco-Management and Audit Scheme) as a requirement of green jobs}

EMAS is the premium environmental management tool to achieve environment friendly activities. It leads to enhanced performance, credibility and transparency of registered organizations. EMAS is a voluntary tool available for any kind of organization aiming to:

- Improve its environmental and financial performance;

- Communicate its environmental achievements to stakeholders and society in general.

Table 3. Numbers of organization certified by EMAS in EU in 2015

\begin{tabular}{|l|c|l|c|}
\hline \multicolumn{5}{|c}{ Organizations which have EMAS 2015 } \\
\hline Country & Organizations & \multicolumn{1}{c|}{ Country } & Organizations \\
\hline IT & 1049 & EE & 7 \\
\hline ES & 908 & LT & 5 \\
\hline DE & 329 & NL & 5 \\
\hline AT & 276 & FI & 4 \\
\hline PT & 56 & BG & $\mathbf{3}$ \\
\hline DK & 48 & RO & 3 \\
\hline PL & 44 & IE & 2 \\
\hline GR & 42 & SK & 2 \\
\hline UK & 40 & LU & 1 \\
\hline CY & 35 & MT & 1 \\
\hline BE & 29 & SE & 1 \\
\hline CZ & 25 & HR & 0 \\
\hline HU & 21 & LV & 0 \\
\hline FR & 13 & SI & 0 \\
\hline NO & 9 & Total & $\mathbf{2 9 5 8}$ \\
\hline
\end{tabular}

Source: EMAS, 2015.

The third revision to the EMAS Regulation has improved the scheme's applicability and credibility and strengthened its visibility and outreach. In Bulgaria EMAS was introduced by Regulation (EC) № 1221/2009 on the voluntary participation of organizations in a Community eco-management and audit scheme (EMAS), which entered into force on 11 January 2010. Unlike industry standards, such as ISO 14001 is, EMAS is integrated into the legal system of the European Union and applied directly by all Member States of the European Union. The EMAS requirements include those of ISO 14001, but with Regulation (EC) № 1221/2009, introducing some new elements that further enhances the credibility of the scheme. This is actually the scheme-standard for environmental management by any organization except that introducing an effective system of environmental management.

Unfortunately Bulgaria is lagging behind of implementing of EMAS and up to 04.2015 is represented only by 3 firms. Data shows (Table 3) that Bulgaria is on one of the last places of EMAS registered organizations, and after are only 9 countries. According to the topic of green jobs creations, that information shows that Bulgaria has no big potential for creating green employment, because only 3 firms are having the needed EMAS certificate. 


\section{SWOT analysis of implementation of green jobs in Bulgaria}

To understand the opportunities and barriers in front of the green jobs is prepared SWOT analysis of Bulgaria in the studied area. Information is summarized on the basis of meetings with experts from municipal and regional structures involved in the implementation of these positions in the country. Summary is offered in table 4.

Some of the advantages of green jobs are connected with transfer of business activities to green ones. This leads to realizing the principles of sustainable development conception and ecologization of economy. Strong side of green jobs creation is that it is mechanism for decreasing unemployment rate. Countries could reach the principles established in national and EU programs through creating green jobs.

Table 4. SWOT analysis of implementation of green jobs in Bulgaria

\begin{tabular}{|c|c|}
\hline $\begin{array}{l}\text { Strong sides (Straights) } \\
\text { Mechanism for decreasing unemployment rates; } \\
\text { Transfer of business activities to green ones; } \\
\text { Ecologization of economy; } \\
\text { Reaching of the principles established in national } \\
\text { and EU programs; } \\
\text { Increasing prestige of the organizations; } \\
\text { Social and ecological responsibilities of business } \\
\text { to environment; } \\
\text { Familiarity with terminology around } \\
\text { climate change, renewable energy, and other } \\
\text { environmental issues. }\end{array}$ & $\begin{array}{l}\text { Possibilities (Opportunities) } \\
\text { Creation of new professions on larger field of } \\
\text { operation; } \\
\text { Requalification of employees; } \\
\text { Facilitation of the procedure of implementation of } \\
\text { green jobs; } \\
\text { Restructuring of employment from different } \\
\text { sectors; } \\
\text { Social security contributions to be paid out by state } \\
\text { budget; } \\
\text { Reaching sustainability more than one year per a } \\
\text { green job under this supporting measure; } \\
\text { Additional benefits to the employer. }\end{array}$ \\
\hline $\begin{array}{l}\text { Weak sides (Weaknesses) } \\
\text { Complicated procedure of applying(employers); } \\
\text { Short term of contracts; } \\
\text { Social security paid by employer; } \\
\text { High requirements for employers; } \\
\text { Lack of a job history; } \\
\text { Low payment per one new created green job. }\end{array}$ & $\begin{array}{l}\text { Threats } \\
\text { Applying of employers to more friendly programs } \\
\text { for employment; } \\
\text { No absorption of the program funds; } \\
\text { Lack of interest of entrepreneur; } \\
\text { Continuing decreasing trend of new created green } \\
\text { jobs; } \\
\text { High price of job creation of a green job compared } \\
\text { to the traditional once. }\end{array}$ \\
\hline
\end{tabular}

Source: According to authors' opinion.

Implementing of green jobs is bringing some advantages for the business organizations such as: increasing their prestige through creating new green jobs and increasing their social and ecological responsibility to environment. Straights of green job are that they are familiar with terminology around climate change, renewable energy and other environmental issues. All this strong sides lead to possibilities of green jobs. One of them is the creation of new professions on larger field of operation. At the same time ecologization of economy through creating green jobs requires requalification of employees. There is restructuring of employment from different economic sectors because of the green jobs. Nowadays some of the jobs disappeared because of the ecological oriented economy of the countries and they are replaced by other different 
jobs which are more ecological such as green jobs. Green jobs create employment which does not cause massive environmental damages. There is also facilitation of the procedure of implementation of green jobs. Other possibility is social security contributions to be paid out by state budget, because at the moment social security contributions is not subsidized and they are paid by the employer. It is possible to make green jobs more sustainable through reaching sustainability more than one year per a green job and additional benefits to the employer. Among the strong sides there are some weaknesses connected mainly with complicated procedure of applying and high requirements which create difficulties for employers. There are also weak sides like a short term of contracts which are for 12 months. Disadvantage of the measure Green jobs is the requirement employer to pay the social security to employee. There is lack of the job history which doesn't help to the manager to evaluate the employee. The payment per one new created green job in Bulgaria is low. Gathered together all weak sides of green jobs are assumed the main threats.

One of the threats is that employers could apply to other more friendly programs for employment, which applying procedure is easier. This leads to no absorption of the funds of measure green jobs. Serious threat in green job creation is high price per one new job in green sector compared to the traditional once. The creation of one green job in some countries (Germany, France) leads to loss of more than four jobs in industrial sectors which are more environmental unfriendly.

\section{General conclusion and policy recommendation}

Based on the analysis of the current conditions of green jobs in Bulgaria are made general conclusions as follows:

$\checkmark$ Green jobs are created in the EU, mainly as a result of environmental policy. Development of green jobs requires interrelated policies governing environmental and social policies. The stress is on environmental dimension and the social dimension is of secondary importance.

$\checkmark$ The number of green jobs in the last decade increased in most of the EU countries as a result of the various policies and initiatives taken at European level in the field of employment and environment. It exceeds the number of jobs in other sectors of the economy where there is a high risk of environmental pollution. There is a loss of jobs in sectors that are not environmentally friendly and create jobs in new sectors imposed by the development of green industry and economy.

$\checkmark$ The number of created green jobs in Bulgaria for the period 2011-2014 is decreasing. This negative trend can be explained with very high requirements on one hand for the employers and on other hand very low payment for the employees.

$\checkmark$ InBulgariaaround $50 \%$ of the firms who implemented ISO are in sector "Constructions", which explains the highest number of green jobs in the same sector.

In Bulgaria are numbers of incentives suitable for employers to hire people. Many

EP 2015 (62) 2 (369-384) 
employment measures are having influence on absorption of funds designed for "green jobs". The procedure for applying for some of these measures has been simplified and the conditions for applying for them are simpler for employers. This leads to redirect unused funds from measure "green jobs" to other measures that are more attractive to employers.

The financial support from measure "Green job" is very low for some of the defined activities. According to this reason business organization which wants to use government support for creating green jobs have tree possibilities. On one hand they could hire only unqualified people and opening positions which do not require special education or qualification. On the other hand they could hire management positions to which they can use that payment as a supporting additional payment or to redirect employment to different programs, which may pay social security, which in program for green job is not included.

$\checkmark$ The knowledge of creation of green jobs in Bulgaria is insufficient. The first statistical evidence is since 2011.

Based on the analysis of the current conditions of green jobs in Bulgaria and problems in this sector are made policy recommendations as follows:

In relation to the labor market should be encouraged undertaken of specific programs to support professional education and qualification of those workers threatened by industrial change and who could lose their current job or level of income.

$\checkmark$ The financial support under the measure "Green job" has to be equal or higher compared to minimum salary in the sector where the position is open. At the moment are observed high differentiations of minimum branch salaries, till the green job payment is fixed. Like this the measure green jobs can become more attractive.

$\checkmark$ Social security contributions have to be paid out by state budget. This will motivate the employers to create green jobs even on this low paid basis. It is possible also employer to receive additional benefits such as qualification courses to the exciting personal connected with the green technologies.

$\checkmark$ The duration of the measure of green jobs has to be longer than 12 months. This will make green jobs more sustainable.

$\checkmark$ It is possible to improve the management of employment measurements. Creating green jobs has to be integrated with existing social employment measures. They should be cooperative between, and transfer possible candidates on the best possible working place. This leads after it to better absorption of the "Green jobs" measure's funds.

$\checkmark$ It is possible to be made structural change of existing administration which aims to support the development of green jobs in Bulgaria. Administrative units should consulate employers about the steps how to achieve eligible criteria to create in his organization green job. 
One of the ways for increasing the number of absorption of the green jobs is via facilitation of the procedure of implementation of green jobs.

\section{Literature}

1. European Commission (EC), (2014): Rural Development Programme for Denmark 20142020, Fact Sheet, European Commission, Brussels, available at: http://europa.eu/rapid/ press-release MEMO-14-2628 en.htm, accessed at: April 2014.

2. European Commission (EC), (2013): European Employment Observatory Review, Promoting green jobs throughout the crisis: a handbook of best practices in Europe 2013, EC, Directorate-General for Employment, Social Affairs and Inclusion, Luxemburg, available at: http://ec.europa.eu/social/BlobServlet?docId=10295\&langId=en

3. Employment agency (2010): Selection procedure for employers by using promoting measures for employment and training under the Low of employment promoting, Measure - hiring unemployed persons with maintained registration at less than 6 months of "green jobs ”, Employment agency, Sofia, Bulgaria, available at: www.az.government.bg/pages/ myarka-naemane-na-bezrabotni-lica-s-neprekasnato-poddarzhana-registraciq-nad-6meseca-na-zeleni-rabotni-mesta/

4. Farrell, C. (2011): Green Jobs Inside the industry, ABDO, Nord Mankato, Minnesota.

5. Harizanova, H. (2015): Implementation of ISO 14001 in Bulgaria, Scientific Papers Series Management, Economic Engineering in Agriculture and Rural Development, vol. 15, no. 1/2015, pp.193-198, available at: http://managementjournal.usamv.ro/ index.php/scientific-papers/current

6. International Organization for Standardization (IOS), (2013): The ISO Survey of Management System Standard Certifications (1999-2013), available at: www.iso.org/iso/ iso-survey

7. Jacobs, M. (1994): Green Jobs? The Employment Implications of Environmental Policy, WWF, Surrey, United Kingdom.

8. Jarvis, A., Varma, A., Ram, J. (2011): Assessing green jobs potential in developing countries, A practitioner 's guide, ILO, Geneva, Switzerland.

9. Llewellyn, B., Hendrix, J. (2008): A Guide to Eco-Friendly Employment, Adams Media publishing, Avon, USA.

10.Luca, L. (2011): The ILO's Rural Employment and Decent Work Programme Unleashing rural development through employment and decent work: A pressing need and timely investment, ILO publishing, Genève, Switzerland, available at: http:/www.ilo.org/ wcmsp5/groups/public/---ed_emp/documents/publication/wcms 158583.pdf

11. Ministry of Labour and Social Policy (2014): National action plan for employment 2014, Ministry of Labour and Social Policy, Sofia, Bulgaria.

12. Miteva, A., Stoyanova, Z., Harizanova, H., Peicheva, M., Doichinova, J., Kanchev, EP 2015 (62) 2 (369-384) 
I. (2014): Green jobs - tool of ecologisation of Bulgarian Economy, Research project, NID NI1-6/2014, Preliminary results, University of national and world economy, Sofia, Bulgaria.

13. OECD (2012): Employment Outlook 2012, Chapter 4 "What Green Growth Means for Workers and Labour Markets: an Initial Assessment”, pp. 163-217, OECD Publishing, Paris, France, available at: www.oecd.org/els/emp/EMO\%202012\%20 Eng_Chapter\%204.pdf

14. Peicheva, M., Harizanova, H., Miteva,A. (2014): Project Research of the needs to conduct social audit and implementation of standards of social and environmental responsibility in Bulgaria, Research project, NID NI1-4/2014, Preliminary results, University of national and world economy, Sofia, Bulgaria.

15. Renner, M. (2008): Green Jobs: Working for People and the Environment, World Watch Institute, Washington DC, USA.

16. Renner, M., Sweeney, S., Kubit, J., Mastney, L. (2008): Green Jobs: Working for People and the Environment, World Watch Institute, Washington DC, USA.

17. Sharma, H. (2011): Green Jobs and Decent Work: An Agenda for Sustainable Agriculture in India, “Will the „BRIC's Decade continue? - Prospects for trade and growth”, IAMO Forum, 23-24 June 2011, Halle (Saale), Germany, pp. 2, available at: http://ageconsearch. umn.edu/bitstream/115366/2/Sharma_IAMO_Forum_2011.pdf

18. Stoevska, V., Hunter, D. (2012): Proposals for the statistical definition and measurement of green jobs, International labour office, Department of statistics, Geneva, Switzerland, pp. 18, available at: www.ilo.org/wcmsp5/groups/public/---dgreports/---stat/documents/ event/wcms 195698.pdf

19. Sustainlabour (2013): Green jobs and related policy frame works - an overview of the European Union, February 2013, report, Sustainlabour, Madrid, Spain, available at: www.sustainlabour.org/documentos/Green $\% 20$ and $\% 20$ decent $\% 20$ jobs- $\% 20 \mathrm{An} \% 20$ Overview $\% 20$ from $\% 20$ Europe $\% 20$ FINAL.pdf

20.UNEP/ILO/IOE/ITUC (2009): Green Jobs: Towards decent work in a sustainable, lowcarbon world, report, Publishing Services Section of United Nations Office at Nairobi, Kenya, available at: www.unep.org/PDF/UNEPGreenjobs report08.pdf

21. EMAS, Reports and statistics, portal EMAS, European Commission, available at: http:// ec.europa.eu/environment/emas/register/reports/reports.do, accessed at: April 2015. 